KlÁrA KovÁcs*

\title{
A COMPARISON OF FACTORS INFLUENCING HEALTH RISK BEHAVIOUR OF COLLEGE STUDENTS IN THE COUNTRIES OF THE CARPATHIAN BASIN**
}

\author{
(Received: 20 September 2017; accepted: 1 July 2018)
}

\begin{abstract}
An examination of the health behaviour of college students is important from several aspects. First, starting and continuing studies, being detached from the family and friends creates a new situation for students (GREENE et al. 2001), the decreasing parental control may test the development of selfregulation in a young person. The chances of harmful forms of behaviour, especially binge drinking, increase among students (VON AH et al. 2004; HunT \& EISENBERG 2010; O’MALLEY \& JOHNSTON 2002). In our study, we intended to find out how individual and socio-economic factors influence the health risk behaviour (smoking, excessive use of alcohol, and drugs) of higher-education students in Central and Eastern European countries. For the analyses, we used a database of the Centre for Higher Education Research and Development (CHERD-H), including the higher education institutions in the border regions of five countries: Hungary, Slovakia, Ukraine, Romania and Serbia (IESA 2015, N = 2,017). Our results show that although the regions concerned share similar historical and cultural traditions, there are different factors influencing the health behaviour of students in the countries concerned. In general, we may state that, with the exception of Serbia, health risk behaviour is more characteristic of male students than of female ones. It is only in Hungary that subjective financial situations play a role in the health-risk behaviour of students in Hungary. The social-partying way of life is a risk factor in almost all the regions concerned. Recreational activity is a protective factor in Hungary against substance use, just as much as sports among the Subcarpathian students. Being familiar with the meaning of life is a protective factor for the students in the Partium and Transylvania. The level and different dimension of individual trust has an inconsistent influence in the specific countries.
\end{abstract}

Keywords: Health risk behaviour, higher education, socio-economic status, trust, meaning of life, leisure activities

* Klára Kovács, Institute of Education and Cultural Management, University of Debrecen; Center for Higher Education Research and Development Hungary (CHERD-H), Egyetem tér 1., H-4032 Debrecen, Hungary; kovacs.klarika87@gmail.com.

** Project no. 123847 has been implemented with the support provided from the National Research, Development and Innovation Fund of Hungary, financed under the K_17 funding scheme. The study was supported by the János Bolyai Scholarship (2016-2019). 


\section{Introduction}

Examining the students' health behaviour is important from a number of aspects. First, starting and continuing studies in higher education for a freshman student, being detached from one's original background, family and friends, the liberation from parental control, all add up to an exciting new experience, but it generates stress in students at the same time (GREENE et al. 2011). Relationships with the family change, and separation becomes a lot more important than the strong family ties. Furthermore, entering campus life, with all the new norms, values, standards and expectations mediated by older students may easily lead to certain forms of behaviour that are harmful to the health of young people. Especially, the increased amount of alcohol consumed as compared to the population outside the campus may present a risk (Von Ah et al. 2004; Hunt \& EISENBerg 2010; O'MALleY \& Johnston 2002). Heavy drinking and the use of drugs will, in turn, lead to risks such as road accidents, unsafe sexual adventures, aggressive behaviour, fights, and even suicide, that all jeopardise the successful completion of college or university studies and may eventually lead to long-term addiction (CRANFORD et al. 2009; WECHSLER et al. 1995; MILLER et al. 2007). In our survey, we wish to identify and examine how certain individual and socio-cultural factors influence the health risk behaviour (smoking, binge drinking, and drug consumption) of students in Central Europe. Various research findings verify that adverse social behaviour phenomena (such as failure at school, crime, violence, drug addiction, undesired pregnancy) often have similar predictors (Hawkins et al. 1999).

College and university students constitute a large and important group of the young adult society. They are going to become the intellectuals of the future, political decision makers, teachers, doctors, etc. They will play an important role in social changes; therefore, their state of health, their behaviour, and their attitudes are going to be examples other segments of society will follow (STEPTOE \& WARDLE 2001; StePtoe et al. 2002). HunT and EISENBERG (2010) assert that an analysis of the students' health behaviour offers a unique possibility to devise targeted intervention schemes to the major health problems of adolescents and young adults. That is why we ascribe great importance to surveying the extent and forms of harmful passions and the individual, as well as social factors, influencing these. It is to be noted that in our research, the role of socio-cultural and social determining factors was examined principally; therefore, a sociological approach prevails over a psychological one. The involvement of individual factors in analyses is justified by papers, e.g. by STEPTOE and WARDLE (2001), STEPTOE and colleagues (2002) HANSON and CHEN (2007), who draw attention to SES as not being as powerful a health behaviour influencing factor among youth as it is among older adults. The role of social and psychological factors is more tangible among the explanatory variables of adolescent and young adult health-risk behaviour (PIKÓ \& FITZPATRICK 2001). The inventory allowed us to examine the influence of the meaning in life, and we decided to test it and to control the involved socio-cultural and societal variables, since the effect of the meaning of life 
on mental well-being has been convincingly demonstrated by previous research findings (STeger et al. 2006; MARTOS \& KonKOlY-Thege 2011; Brassai 2011).

For our analyses, we used the database of Centre for Higher Education Research and Development (CHERD-H). We gathered data from students in Hungary and ethnic Hungarian students studying in higher-education institutions in the border zones of four neighbouring countries (Slovakia, the Ukraine, Romania, and Serbia) (IESA 2015, $\mathrm{N}=2017) .{ }^{1}$ At the institutions in the neighbouring countries we examined, the majority of the students are ethnic Hungarians. These areas share their historical and cultural roots with Hungary, since these regions had been parts of Hungary and were ceded to the new and/or neighbouring countries at the Versailles Treaty in $1920 .{ }^{2}$ After 1920, these areas, including their educational systems, were exposed to new economic, historical, and political influences. We therefore included the differences between the countries concerned in our research, in order to find the similarities and differences in the factors influencing health risk behaviour. We selected institutions in Hungary where at least $15 \%$ of the students come from an underprivileged background. This was based upon the applicants' claim for extra entry points because of their underprivileged status (HEGEDÜs 2016). The institutions of North-Eastern Hungary stand out of the national average in that respect and, as they are located geographically close to some of the ethnic institutions on the other side of the border, we found it relevant to compare these students with those of the institutions in the neighbouring countries. Our observations, however, were not restricted to finding the interrelations: we examined the factors influencing health risk behaviour separately in each country.

An examination of the health behaviour of Eastern European students is also necessitated by the fact that, as indicated by various research findings, a higher occurrence of unhealthy ways of life in this region is not primarily explained by individual choice and decisions. The difficulties following the change of the political system (1990) were manifested in worse poorer chances and worse ways of life. A fundamental political and economic re-structuring of the entire system of institutions has been causing chronic social stress and an impression of uncertainty, leading to a sense of lack of control in people (STEPTOE \& WARDLE 2001).

Earlier research programmes, including those dealing with binge drinking, primarily concentrated on one single higher-education institution or, when institutions were selected for sampling, the process was influenced by aspects of convenience. Multi-institution, and especially multi-country comparisons, are scarce (WECHSLER et al. 1995). A welcome exception is the longitudinal survey conducted by STEPTOE

\footnotetext{
Institutional Effects on Students' Academic Achievement (IESA) coordinated by CHERD-Hungary (Center for Higher Education Research and Development) at the University of Debrecen.

2 The former territories of Hungary that now belong to Romania are called Partium and Transylvania, those in the Ukraine are referred to as Subcarpathia, and those in Serbia are called Voivodina. The students participating in our survey come from these territories, so the names of the countries will be used synonymously with the territories listed above. It is to be noted, however, that our results and findings only apply to the institutions of these territories, and they are not representative of the entire countries.
} 
and colleagues (2002), extended to 13 countries (including Hungary as the only Central European one). They examined the health risk behaviour of more than 20,000 students in 1990 and 2000. They found that among Hungarian students, smoking increased considerably while physical activity declined. Similarly, fruit consumption declined, and fat consumption increased. The figures applied to both sexes. All in all, a high cardiovascular risk behaviour was universally prevalent (STEPTOE et al. 2002; BARANYAI et al. 2006).

\section{The Factors Determining the Health Behaviour of Students}

The factors influencing, and jeopardising, young people's health behaviour basically fall into two categories. The first one is the social and cultural system in a broad sense, including legal regulations, cultural norms, values, and the behaviour patterns that serve as an example in using alcohol and drugs. The second is the direct interpersonal environment surrounding the individual: family, peer group, school and classroom. In order to develop efficient prophylactic programmes, it is indispensable to reveal the ethological roots of substance use and also to test the efficiency of the existing policies and programmes. The next step is the identification of the factors influencing the individual's use of drugs in various dimensions (individual, family factors and interactions, school and peer group experience, legal, economic, and cultural factors, etc.). It is also necessary to monitor the changes in the composition and effect of the negative factors that take place with aging. Finally, it is to be noted that the higher the number of negative factors that exist in the present, the more powerful effects they are going to have in the future (HAwKINS et al. 1992). In the rest of the study, we list some - though certainly not all - factors that influence university students' health risk behaviour, and discuss the functions and role of some of those factors.

\subsection{Socio-Cultural and Demographic Background}

Social background, as verified by meta-analyses, is not as powerful a health behaviour influencing factor among youth as it is among older adults. Poor nutrition, a less active life, and a higher rate of smoking are, however, more characteristic among young people (10-21 years) of lower social status. There is no clear-cut pattern for the consumption of alcohol or marijuana (HANSON \& CHEN 2007). It is to be noted that the members of the campus society usually come from families of a higher social status, and they are more health conscious than people at the lower levels of society. Social background is therefore not so strongly influencing the health behaviour of students as that of adults (STEPTOE \& WARdLE 2001; STEPTOE et al. 2002; HANSON \& CHEN 2007).

Various research projects from the USA and international corporative European surveys (from Belgium, England, France, Germany, Greece, Hungary, Iceland, Ireland, Italy, the Netherlands, Poland, Portugal, and Spain) have verified that forms of health risk behaviour (binge drinking, drug consumption) are more characteristic of male students (though the differences in smoking between the two sexes appear to 
level out). Women and students coming from a lower social-economic status are overrepresented among those with mental problems and a low level of physical activities. Women are more conscious in matters of food and eating (CRANFORD et al. 2009; STEPTOE et al. 2002; EMmONS et al. 1998; Hunt \& EisENBERg 2010; VAeZ \& LAFLEMME 2003). In a multi-variable model, WECHSLER and colleagues (1995) found men, people under 21, and whites more susceptible to binge drinking. CRANFORD and colleagues (2009) pointed out that undergraduate students are likely to drink more and use marijuana than graduate students.

Our research addresses one of the most underprivileged regions in Hungary (and in the entire EU), that is: the North Plains Region and the adjacent cross-border areas. In the neighbouring countries, we primarily involved ethnic Hungarian students in the research. Since the proportion of students from an underprivileged background is higher than the average (a total of 15\%) (HEGEDÜs 2016), an examination of the variables of the socio-economic background is fully relevant. The research findings will contribute to the identification of the social groups that are exposed to high risks of unhealthy lifestyles within the student population, as well. In Hungary and Romania, the socio-economic background was analysed at students' self-evaluation of their health in the upper classes of secondary school. The major difference between the two countries was that in the case of the Transylvanian students, the unemployment of the parents had the most important role. The researchers found that the socio-economic background plays a different role in the case of young people than in the case of adults (PIKó et al. 2013).

In our former research in the region, when we carried out a controlled examination of the evolution of risk avoiding attitudes, we found that a woman had twice as high a chance to avoid health damaging habits than a man. It is an important recognition that the institutional background has an importance exceeding that of the personal status. In the generally risk-avoiding campus environment, a student has twice as high a chance to avoid harmful activities and dimensions of life than in the outside world. The powerful, multidimensional embeddedness into the world of peers significantly increases the chances of successful risk avoiding attitudes (PUSZTAI et al. 2017).

\subsection{Social Effects}

Peer influence is one of the most obvious predictors of young people's substance use. This effect very often comes as a pressure from peers in the course of some sort of an 'inauguration', so the smoking and binge drinking of peers is a serious risk factor in young people's substance use. It applies to all three forms of risk behaviour that the real or alleged substance use of peers motivates young people to try the substance themselves. Peer influence is closely linked to the fact that in adolescence, the social network is restructured; the individual is now more independent of parents, and peer groups become more important for young people. Peer influences, (friends) do not necessarily entail adverse effects and risk factors. They may just as easily serve as effective community-forming effects and improve the coping ability of young people 
(PIKÓ 2002; 2010; HaWKINS et al. 1992). When the individual is able to build up a close, well-functioning social-support network around themselves (either with parents and family, or with friends), the presence of a powerful health protecting effect is observable. The existence - or lack - of connections, the quality and quantity of these connections, determine the individual's physical and mental well-being, so these may serve as a serious protective factor. Individuals with a stable system of connections are less susceptible to depression, and they tend to have fewer psychosomatic diseases. They are, in turn, less likely to reach for hazardous substances (it was found among college and university students that fewer individuals possessing such a system of connections tended to smoke and they consumed less alcohol; VON $\mathrm{AH}$ et al. 2004). It is therefore clear that the effect of peers may be dual from the aspects of health risk behaviour.

The higher parental support, control, and monitoring that are present, the more confidential the relationship between parent and child, the lower the risk of the child's smoking and substance use. In the opposite case, family conflicts and poor links between parent and child, are serious risks that lead to the individual's substance use and other problems in adolescence (HAWKINS et al. 1992). We have been able to verify this in our research into the substance use of the students of the University of Debrecen (KovÁCs 2012). The parental role, however, changes when the child enters higher education, since most of these students move away from home (into students' lodgings (dorm), where they share the place, usually with other students). Still, students continue to depend upon their parents to some extent (especially financially), though parental monitoring decreases. However, in this age group, overly powerful parental monitoring and control may become a burden on children, rather than a protective factor for them. Students follow their own preferences when they become members in various peer groups in college/university communities, and choose their own free time activities, in which fellow students and friends usually play an important role. Peer communities have a very powerful effect on college/university students. Students regard teachers as elitists, and do not see in them the example to follow. Instead, they are attracted to the small communities that their fellow students create (e.g. sports clubs, student associations), adapting the values, norms, and customs of these groups (PUSZTAI 2011).

It is emphasised in several research reports that social activities related to student life, especially leisure time activities, belonging to student communities are outstanding predictors of health risk behaviour. Partying, and belonging to various student associations, (fraternity, sonority), characteristic primarily of the American universities, are always serious predictors (CRANFORD et al. 2009). In their research, PiKó and BRASSAI (2007) examined the role of values in certain dimensions of the health behaviour of students from Szeged (Hungary) and Marosvásárhely (Tirgu Mures, Romania). They found that in both sub-samples, social values, gentleness, familism and collectivism come together with lower substance use. In the examination serving as a basis for the essay, we confirmed the influence of the partying and the sporty ways of spending free time on the main component of health risk behaviour. 
The more characteristic an individual's ways of spending free time are, the more likely the occurrence of substance use, regardless of all the other socio-cultural and demographic factors.

Interrelation between doing sports and different forms of health risk behaviour is not yet fully clear (MARTENS et al. 2006; TALIAFERRO et al. 2010): although students engaging in sports are usually not smokers (KovÁcs 2012); but when a male student does not participate in any sport or finds sport unimportant, that may serve as a predictor of smoking. Belonging to sports communities usually comes together with a higher degree of alcohol consumption (particularly among top-level athletes). On the other hand, religion, and belonging to religious communities, serve as a protective factor against smoking and excessive alcohol consumption (EMMONS et al. 1998; WECHLER et al. 1995). We may, however, find surveys that have been unable to detect interrelation between doing sports and risk behaviour among students (SZATMÁRI et al. 2012).

In the social development model about the school behaviour of children (HAWKINS \& WEIS 1985) the strong ties to various communities (prosocial family, school, peers) - or, in the case of college and university students, integration into the campus (PUSZTAI 2015) - serves as a protective wall against behavioural disturbances, truancy, and other school problems. In theory, it is assumed that when the community establishes strong bonds between its members, and makes the rules of behaviour clear to all of them, it thus ensures that the group members' behaviour and attitudes are then going to be regulated by the rules that are set. The model hypothesises that children need to learn patterns of behaviour, whether prosocial or antisocial, from their social environment as part of their process of socialisation (CATALANO et al. 2004). It is, notwithstanding, necessary to emphasise that better school results and the reduction of health risk behaviour will only be brought about if and when there are also strong bonds between the individual and the institution, and the community of peers relays positive examples and a value system related to health behaviour. The essence of the multi-component theory is that a wide range of risk and protective factors are to be included in the analysis in order to explain and predict the various forms of substance use. An empirical test identified the dominance of four factors that work against substance use; that is, protective factors: (1) strong ties to the parents, (2) commitment to school, (3) regular participation in church activities, and (4) a belief in general social norms, values, and expectations. The impact assessment of the theory, however, did not completely justify the more positive attitude of the participants to their health. Among the students participating in the intervention programme, the occurrence of health risk behaviour was not convincingly lower. The presence of more positive health attitudes among the students had been assumed but was not eventually verified: no lower rate of smoking, alcohol, or drug use was detected in the long run (HAwKINS et al. 1992; 1999).

In our research, based primarily upon this model, we wished to find out to what extent respondents as individuals trusted in other human beings, the willingness of people to help, their honesty. The degree of trust is one of the important indicators in Putnam's social capital concept (PUTNAM 1995) and, as shown by earlier 
research findings, the degree of trust in others has a direct influence on health (SKRABSKI 2003) and the substance use of young people. A survey conducted among Japanese secondary school students found that the individual trust is in a negative correlation with the frequency of smoking and alcohol consumption both with boys and girls (TAKAKURA 2011).

\subsection{Mental and Psychological Factors}

The objectives of our research did not include a detailed examination of the impact of mental and psychological factors, but some individual factors were involved in our model to test the effects of these and to control the influence of socio-cultural variables. A number of mental and psychological factors affect the health-risk behaviour of adolescents and college students: for example, greater sensation seeking, lower levels of conscientiousness, and a higher degree of openness to experience (BERG et al. 2011; BOGG \& ROBERTs 2004), self-esteem (CROLL et al. 2002), cognitive restraint (GREENE et al. 2011), depressive symptoms, and stressful life events (SIMANTOV et al. 2000). In this subchapter, however, we concentrate on the ones that are relevant to our research. Mental and psychological factors play an important role in substance use, which is not surprising, since the occurrence of mental diseases and other mental problems occur among students in higher numbers than in the population outside higher education (HUNT \& EISENBERG 2010): depression, anxiety, a high degree of stress increase the chances of smoking (CRANFORD et al. 2009). The symptoms of depression and anxiety go hand in hand with social stressors and lower social support (HUNT \& EISENBERG 2010), so they may indirectly increase the likelihood of substance use among students. In PIKó's (2002) research findings, smoking, alcohol and drug use are usually characteristic of young people who do not have a stable view of their future, and their behaviour is largely determined by the events of the moment. When the individual has a positive self-image, that is, they have specific goals and believe that they are able to achieve those goals (BANDURA 1977), that is a powerful protective factor against substance use (also) among students. In a survey, several factors were analysed, and only self-efficacy was found to play a role in every form of health behaviour. A high degree of self-efficacy reduced the degree of alcohol consumption and contributed to more frequent physical activity and healthier eating, but was a predictor of smoking. Contrary to the original assumptions, the survey did not reveal any significant correlation between stress, peer support, and substance use (VON AH et al. 2004). In the face of these results, we intended to examine the interrelations between the purpose of life and the risky forms of health-behaviour, analysing views of life, and orientation in connection with the individual's future. We wished to find out whether students know what the purpose of their lives is, or whether they are still looking for a future goal, and how positively they see their personal future (STEGER et al. 2006; MARTOS \& KONKOLY-THEGE 2012; BRASSAI 2011). 


\section{Sample and Methods}

In our research, we wished to find an answer to the following questions: 1) what sociocultural, demographic, and other factors influence students' health behaviour in the Northern Plains region of Hungary, and that of the ethnic Hungarian students in four neighbouring countries (smoking, alcohol and drug consumption), 2) what protective and risk factors can be identified in the areas concerned, and 3) what are the predictors of the risk factors in each of these countries. For the analysis, we used the database of our last research from the Centre for Higher Education Research and Development (CHERD-H) gathered with an inventory in the higher education institutions in the border regions of five countries (Hungary, Slovakia, the Ukraine, Romania and Serbia) (IESA 2015, N = 2,017). The pool for sampling was determined in accordance with the data supplied by the institutions concerned. The numbers of sample elements were created in proportion to the numbers of students at the faculties and institutions. The number of students is therefore much higher in the sample from Hungary than that of ethnic areas. We planned a $20 \%$ sample from the second year of the undergraduate training, and a $50 \%$ sample at the 1 st year of the postgraduate and in the 4th year of the teacher-training courses. We contacted the students in groups at their college/university courses. The groups were selected randomly (PUSZTAI \& CEGLÉDI 2015). ${ }^{3}$ For our survey, we selected institutions in Hungary where at least $15 \%$ of the students come from an underprivileged background. This was based upon the applicants' claim for extra entry points because of their underprivileged status (HEGEDÜs 2016). The institutions of North-Eastern Hungary stand out of the national average in that respect and, as they are geographically located close to some of the ethnic institutions on the other side of the border, we found it relevant to compare these students with those of the institutions in the neighbouring countries. For the major social, demographic, and educational characteristics of the subsamples by countries, see Table 1 below.

We examined three dimensions of the health risk behaviour: the frequency of smoking, binge drinking, and drug use over the past year. However, an important difference exists between substance-using and addictive behaviour; in our research we examined the prevalence and determining factors of health-risk behaviours. The answer alternatives were coded into a scale $0-100$, where 0 indicated that no such events took place, whereas 100 referred to these events as daily routine (Msmoking $=25.88, \mathrm{SD}=37.74 ;$ Mbinge drinking $=29.72, \mathrm{SD}=28.56 ; \mathrm{Mdrug}=3, \mathrm{SD}=12.97$, $\mathrm{N}=1,961)$. In order to examine the impact of all the variables concerned in one

\footnotetext{
The researched institutions were the University of Debrecen $(n=1061)$, the Debrecen Protestant Theological University $(n=22)$, the College of Nyíregyháza $(n=134)$ (Hungary, $n=1223)$; the Sapientia Hungarian University of Transylvania $(n=126)$, the University of Nagyvárad (Oradea) $(n=15)$, the BabeşBolyai University $(n=138)$, Partium Christian University $(n=40)$ (Romania, $n=284)$; Constantine the Philosopher University in Nyitra (Nitra) $(n=56)$, János Selye University $(n=102)$ (Slovakia, $n=158)$; the State University of Munkács (Mukachevo) $(\mathrm{n}=54)$, the Ferenc Rákóczi II. Transcarpathian Hungarian Institute $(\mathrm{n}=72)$, the University of Ungvár $(\mathrm{n}=101)$ (Uzhhorod, Ukraine, $\mathrm{n}=212)$, and the University of Újvidék (Novi Sad, Serbia, $\mathrm{n}=66$ ).
} 
Table 1

Social, Demographic and Educational Characteristics of the Subsamples by Countries in Percentage and Average of Years. (Source: IESA 2015)

\begin{tabular}{|c|c|c|c|c|c|c|c|}
\hline & & Hungary & Romania & Ukraine & Serbia & Slovakia & $p$ \\
\hline \multirow{6}{*}{ Year } & $I$. & 30 & 17.6 & 21.5 & 16.1 & 40.1 & \multirow{7}{*}{0.000} \\
\hline & II. & 57.9 & 64.2 & 51.3 & 59.7 & 28.3 & \\
\hline & III. & 6.6 & 13.7 & 11.8 & - & 5.9 & \\
\hline & $I V$. & 3.9 & 0.3 & 6.1 & - & 11.2 & \\
\hline & $V$ & 1.2 & 3.5 & 9.2 & 24.2 & 14.5 & \\
\hline & $V I$. & 0.3 & 0.6 & - & - & - & \\
\hline$N$ & & 1152 & 313 & 228 & 62 & 152 & \\
\hline \multirow{3}{*}{$\begin{array}{l}\text { Training } \\
\text { form }\end{array}$} & $B A / B S c$. & 60.8 & 92.1 & 87.9 & 58.7 & 62.8 & \multirow{4}{*}{0.000} \\
\hline & MA/MSc./Specialist & 26 & 7.2 & 12.1 & 41.3 & 37.2 & \\
\hline & Undivided training & 13.2 & - & - & - & - & \\
\hline$N$ & & 1169 & 304 & 239 & 63 & 156 & \\
\hline Age & & $22.4 \pm 2.57$ & $22.6 \pm 3.7$ & $19.9 \pm 1.7$ & $22.6 \pm 1.8$ & NA. & \multirow[b]{2}{*}{0.000} \\
\hline$N$ & & 1172 & 280 & 203 & 62 & NA. & \\
\hline \multirow{2}{*}{ Gender } & Female & 69.9 & 83.6 & 70.6 & 95.2 & 68.4 & \multirow{3}{*}{0.000} \\
\hline & Male & 30.1 & 16.4 & 29.4 & 4.8 & 31.6 & \\
\hline$N$ & & 1165 & 318 & 235 & 62 & 155 & \\
\hline \multirow{3}{*}{$\begin{array}{c}\text { Type } \\
\text { of } \\
\text { residential } \\
\text { settlement }\end{array}$} & village & 27.8 & 46.7 & 77.1 & 57.1 & 66.5 & \multirow{4}{*}{0.000} \\
\hline & town & 41.3 & 28.9 & 18.5 & 39.7 & 29.7 & \\
\hline & city & 30.9 & 24.4 & 4.4 & 3.2 & 3.9 & \\
\hline$N$ & & 1167 & 315 & 227 & 63 & 155 & \\
\hline \multirow{3}{*}{$\begin{array}{c}\text { Father's } \\
\text { educational } \\
\text { level }\end{array}$} & Low & 5.1 & 7.4 & 7.2 & 15.9 & 2.7 & \multirow{4}{*}{0.000} \\
\hline & Middle & 70.5 & 77.3 & 73.2 & 69.8 & 85.7 & \\
\hline & High & 24.4 & 15.3 & 19.6 & 14.3 & 11.6 & \\
\hline$N$ & & 1139 & 309 & 224 & 63 & 147 & \\
\hline \multirow{3}{*}{$\begin{array}{l}\text { Mother's } \\
\text { educational } \\
\text { level }\end{array}$} & Low & 4.4 & 8.7 & 8.8 & 14.3 & 2.7 & \multirow{4}{*}{0.000} \\
\hline & Middle & 61.7 & 74 & 61.2 & 68.2 & 79.6 & \\
\hline & High & 33.9 & 17.3 & 30 & 17.5 & 17.7 & \\
\hline$N$ & & 1148 & 311 & 227 & 63 & 147 & \\
\hline
\end{tabular}


model in all the countries by linear regression analysis, we arranged the variables of the three forms of health-risk behaviour in one single component. Through a main component analysis, the variables were arranged into a main component (maximum likelihood method, direct oblimin rotation, $\mathrm{KMO}=0.603$, total variance explained $54.1 \%$ ), the weighs of the main components of which were coded into a scale of $0-100(\mathrm{M}=15.41, \mathrm{SD}=16.76, \mathrm{~N}=1,961)$.

Social effects were measured with the quality of relationship with parents, and the frequency of the individual's involvement in social free-time activities. We examined the parental role through the following factors: how often do they have a chat, how often do parents inquire about the various aspects of their children's life and studies $^{4}$ (index, $0-100$, combined, $\mathrm{M}=62.52, \mathrm{SD}=1.93, \mathrm{~N}=1,589$ ), which is called relationship with parents (PUSZTAI 2011; 2015). For examining the ways students spend their free time, we used 19 activities, and through a factor analysis, we identified four free time preferences. These are the consumption of high culture (going to theatre, museum, gallery, classical concert, exhibition, art cinema etc. $)(\mathrm{M}=25.35, \mathrm{SD}=$ $17.82)$, social and partying activities, $(M=53.79, S D=15.99)$, sports $(M=28.56$, $\mathrm{SD}=14.32)$ and recreational $(\mathrm{M}=59.7, \mathrm{SD}=14.91)$ ways of spending free time. ${ }^{5}$ The values of factor scores were recoded into $0-100$ points scales, where 0 means if a sport attitude or leisure preference is not typical, 100 means it is very typical.

The Meaning in Life Questionnaire (STEGER et al. 2006; MARTOS \& KONKOLY THEGE 2011; BRASSAI 2011) was used for mapping the students' ideas about the point of life as they see it. The items were arranged into two factors (the factor weighs were again recoded into a scale): knowing the meaning of life $(\mathrm{M}=57.9, \mathrm{SD}=25.22, \mathrm{~N}$ $=2,017)$ and seeking the meaning of life $(\mathrm{M}=51.46, \mathrm{SD}=23.02, \mathrm{~N}=2,017)$. The trust scale consisted of three questions: to what extent do you agree with the statement that people usually want to exploit you, how helpful are people, and how trustworthy are people. The items were converted into a scale of $0-100(\mathrm{M}=46.69, \mathrm{SD}$ $=2.19, \mathrm{~N}=1,504)$, but in the analyses, we examined the correlations separately.

We included the most important social-demographic variables into the explanatory variables: country, gender, qualifications of the parents, type of residential settlement, relative and objective financial situation. For an analysis of the students' relative financial situation, respondents were requested to categorise themselves depending on whether they have financial problems and of what kind, or whether they have everything they need. For the examination of students' objective financial situation, they were asked whether their families possessed any or all of the assets in a list. ${ }^{6}$ The

4 items: 1. talk with you; 2. talk with you about culture, politics, public topics; 3 . talk with you about book, movies; 4. talk with you about your future plans; 5 . get a line on your free time; 6 . involve you in chore; 7. get a line on your studies; 8 . meet with your friend(s); 9 . support you financially; 10 . organise cultural program with you; 11. motivate, encourage you to study; 12 . maintain contacts with the faculty staff.

For the characteristics of each factor see Kovács's (2015) study.

Students were requested to indicate the assets that their families possessed on the following list: a flat of their own, a detached house, a weekend cottage, hobby garden, plasma- or LCD TV, desktop- or laptop computer with Internet access at home, tablet, e-book reader, mobile Internet (on phone or tablet), dishwasher, air conditioning, smart phone and automobile. 
possible answers were recoded into a list of 0 to 100 , where 0 meant that they had none of the items, and 100 that they possessed all. Then we recoded the responses into a dummy variable ( 0 : below average, 1 : above average).

SPSS 23 software package was used to carry out the analysis. We applied Spearman's correlation, ANOVA, and linear regression.

\section{Results}

In the main component of health risk behaviour, Slovakian students scored the highest $(\mathrm{M}=18.29, \mathrm{SD}=20.21)$, followed by the Hungarian $(\mathrm{M}=16.67, \mathrm{SD}$ $=16.45)$, Serbian $(\mathrm{M}=16.02, \mathrm{SD}=17.25)$ and Romanian students $(\mathrm{M}=12.46, \mathrm{SD}$ $=15.67)$. The scores of the Ukrainian students were the lowest $(\mathrm{M}=11.13, \mathrm{SD}$ $=15.89)(\mathrm{F}=9.353, \mathrm{p}=0,000)$. Binge drinking is the highest among the Serbian students $(\mathrm{M}=42.22, \mathrm{SD}=42.67)(\mathrm{F}=22.725, \mathrm{p}=0.000)$, while smoking is the lowest $(\mathrm{M}=15.87, \mathrm{SD}=27.39)$. Students in the Highlands are the heaviest smokers $(\mathrm{M}=28.76, \mathrm{SD}=38.34)(\mathrm{F}=4,409, \mathrm{p}=0.001)$, and they also stand out in drug use $(\mathrm{M}=6.79, \mathrm{SD}=19.83)$. Drug use is, on the other hand, not characteristic of the students of the Voivodina $(\mathrm{M}=1.58, \mathrm{SD}=12.59)(\mathrm{F}=4,267, \mathrm{p}=0.002)$. The outstanding smoking and drug use of the Slovakian students resulted in their highest score in health risk behaviour. Health risk behaviour is more characteristic of males $(\mathrm{M}=20.95, \mathrm{SD}=20.22)$ than females $(\mathrm{M}=13.43, \mathrm{SD}=14.86)$.

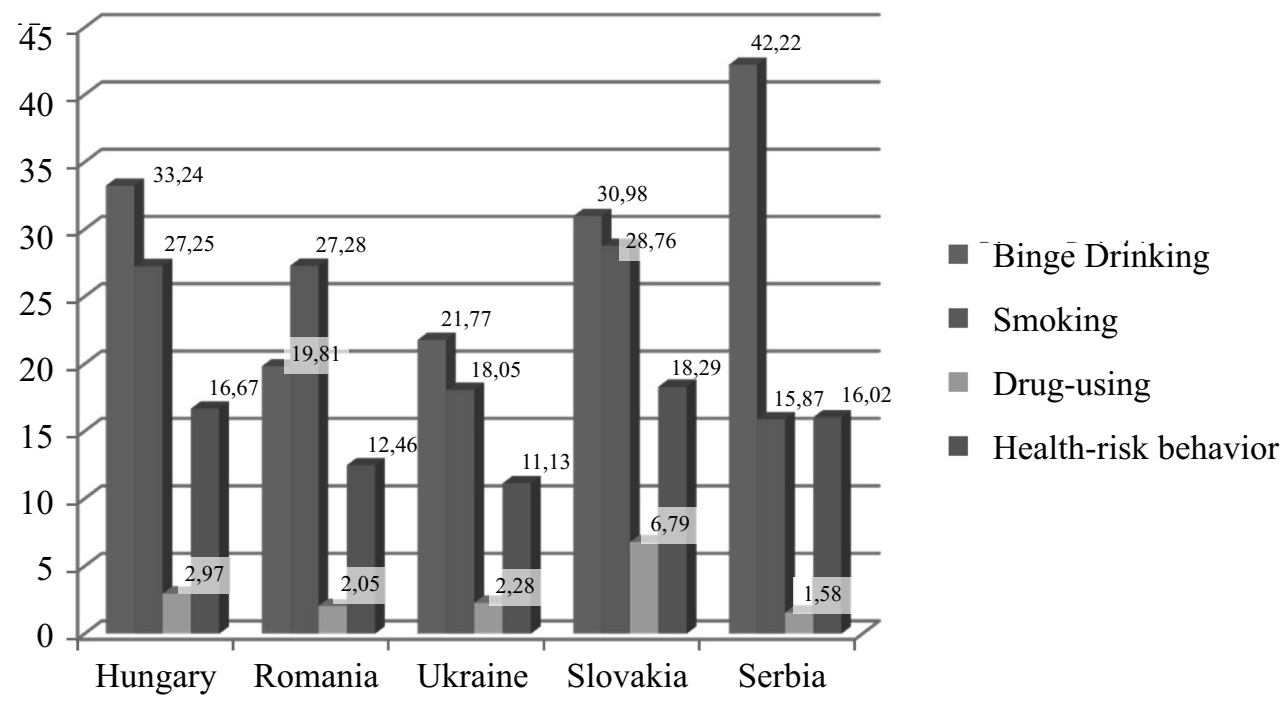

Figure 1

Smoking, binge drinking, drug use and the main component of health risk behaviour in a breakdown according to the countries concerned (points on a $0-100$ scale).

Source: IESA $2015(\mathrm{~N}=1,957)$. 


\subsection{The Role of Socio-Cultural and Demographic Factors in Substance Use}

In the following, we wish to examine whether we find any significant difference(s) in the socio-cultural determining factors of alcohol and drug consumption, smoking and the main component of health risk behaviour (Table 2). With the exception of the sub-sample from the Voivodina, we found considerable differences between the two genders, on the side of the men. Among the Serbian students, the issue of gender is not relevant, since there were only three males in the sample. The profile of the course was a lower primary school teacher. The males scored higher in all the other four countries, especially in Slovakia, so substance use is the highest there $(M=30.1$, $\mathrm{SD}=27.12$ ), whereas the women of Subcarpathia appear to be the least characterised by health-risk behaviours $(\mathrm{M}=7.81, \mathrm{SD}=13.41)$. It is clear from our findings that binge drinking is likely to be the gravest problem, in which there are considerable differences in the four countries. Binge drinking is primarily characteristic of men. In accordance with earlier research findings (WECHSLER et al. 1995), gender differences in smoking have disappeared among Hungarian and Transylvanian students. Male students in the Highland seemed to smoke the most, and Subcarpathian women the least $(\mathrm{M}=10.36, \mathrm{SD}=29.91)$. Large differences were detected in drug use in Hungary, Romania, and Slovakia. Men tend to use drugs more often, especially the male students of Slovakia $(M=17.14, \mathrm{SD}=29.43)$, who use seven times as many drugs as women do $(\mathrm{M}=2.45, \mathrm{SD}=11.61)$.

In a breakdown according to settlement types, we found significant differences in binge drinking in the Hungarian sub-sample, and smoking among Slovakian students. Among Hungarian students, the degree of risk behaviour and the occurrence of heavy drinking increases with the size of the residential settlement; both are more characteristic of students coming from big towns and cities $\left(\mathrm{M}_{\mathrm{HRB}}=18.76, \mathrm{SD}\right.$ $\left.=17.91 ; \mathrm{M}_{\text {Smoking }}=37.07 ; \mathrm{SD}=28.41\right)$. Students coming from smaller towns in Slovakia tend to use a lot of drugs $(\mathrm{M}=39.56, \mathrm{SD}=44.31)$; in Slovakia, those who come from big cities score the lowest in that respect $(\mathrm{M}=6.66, \mathrm{SD}=16.32)$.

It was again the Hungarian and Slovakian student populations where the qualifications of the parents were influential in some of the dimensions. With Hungarian students, we observed that if both parents have secondary qualifications, drug use is the lowest among their children $\left(\mathrm{M}_{\mathrm{f}}=2.2, \mathrm{SD}=10.59 ; \mathrm{M}_{\mathrm{m}}=2.07, \mathrm{SD}=10.74\right)$. Social inequalities are also tangible when it comes to qualifications, since the children of parents with low qualifications are exposed to the use of drugs to a larger extent $\left(\mathrm{M}_{\mathrm{f}}=6.55, \mathrm{SD}=20.3 ; \mathrm{M}_{\mathrm{m}}=6.66, \mathrm{SD}=21.03\right)$. In the case of the students in Hungary, the occurrence of binge drinking increases with the higher qualifications of the mother, whereas in the Highlands it increases with the higher qualifications of the father (highest scores: $\mathrm{M}_{\mathrm{HU}}=36.59, \mathrm{SD}=28.57 ; \mathrm{M}_{\mathrm{SK}}=43.52, \mathrm{SD}=24.52$ ). Similarly, we detected outstanding statistics of smoking in the case of the children of highly qualified mothers in the Highlands $(\mathrm{M}=46.15, \mathrm{SD}=44.09)$.

The effects of higher income, earned with better qualifications, are verified by the higher scores achieved by students in a better objective financial situation at both 


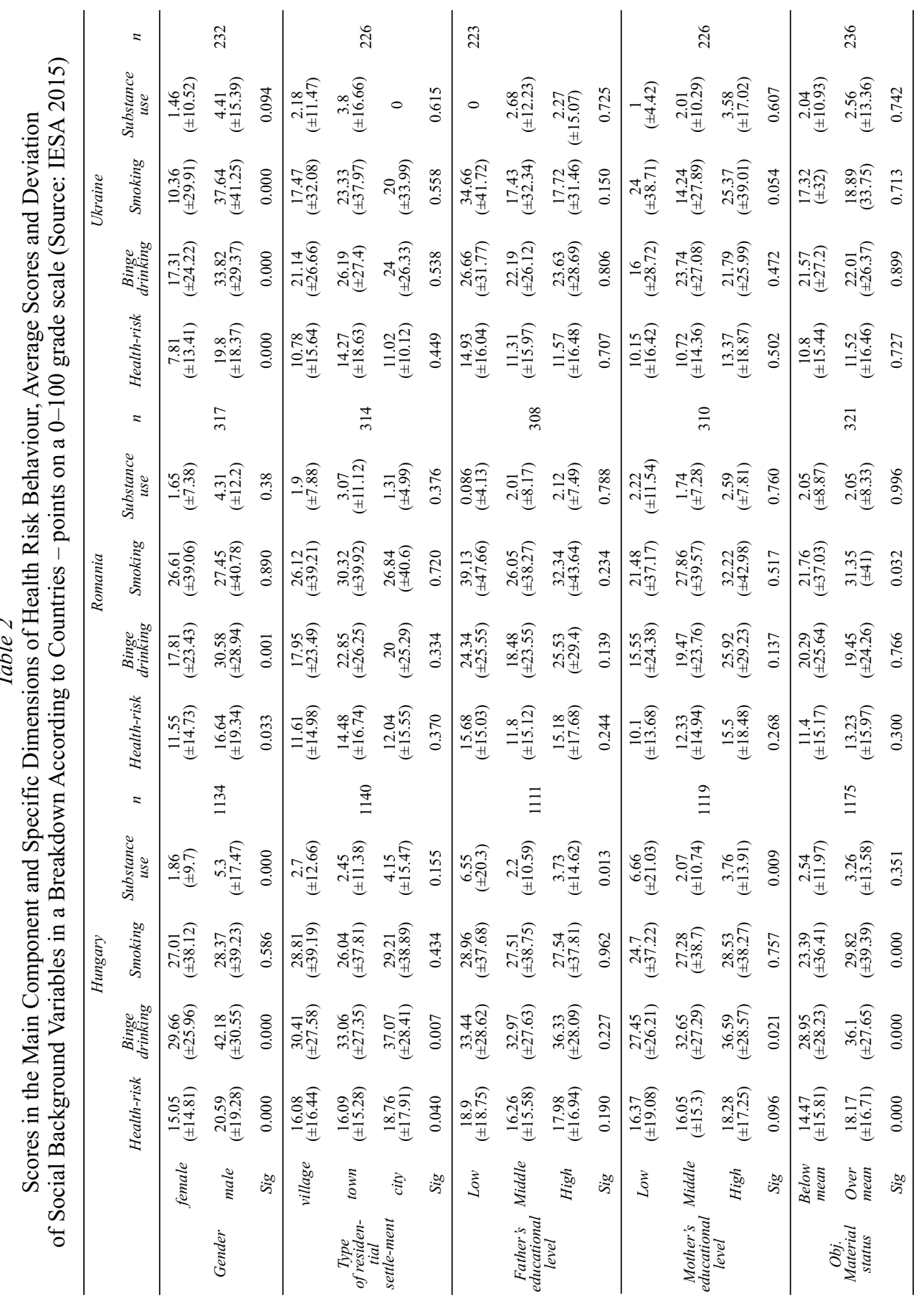




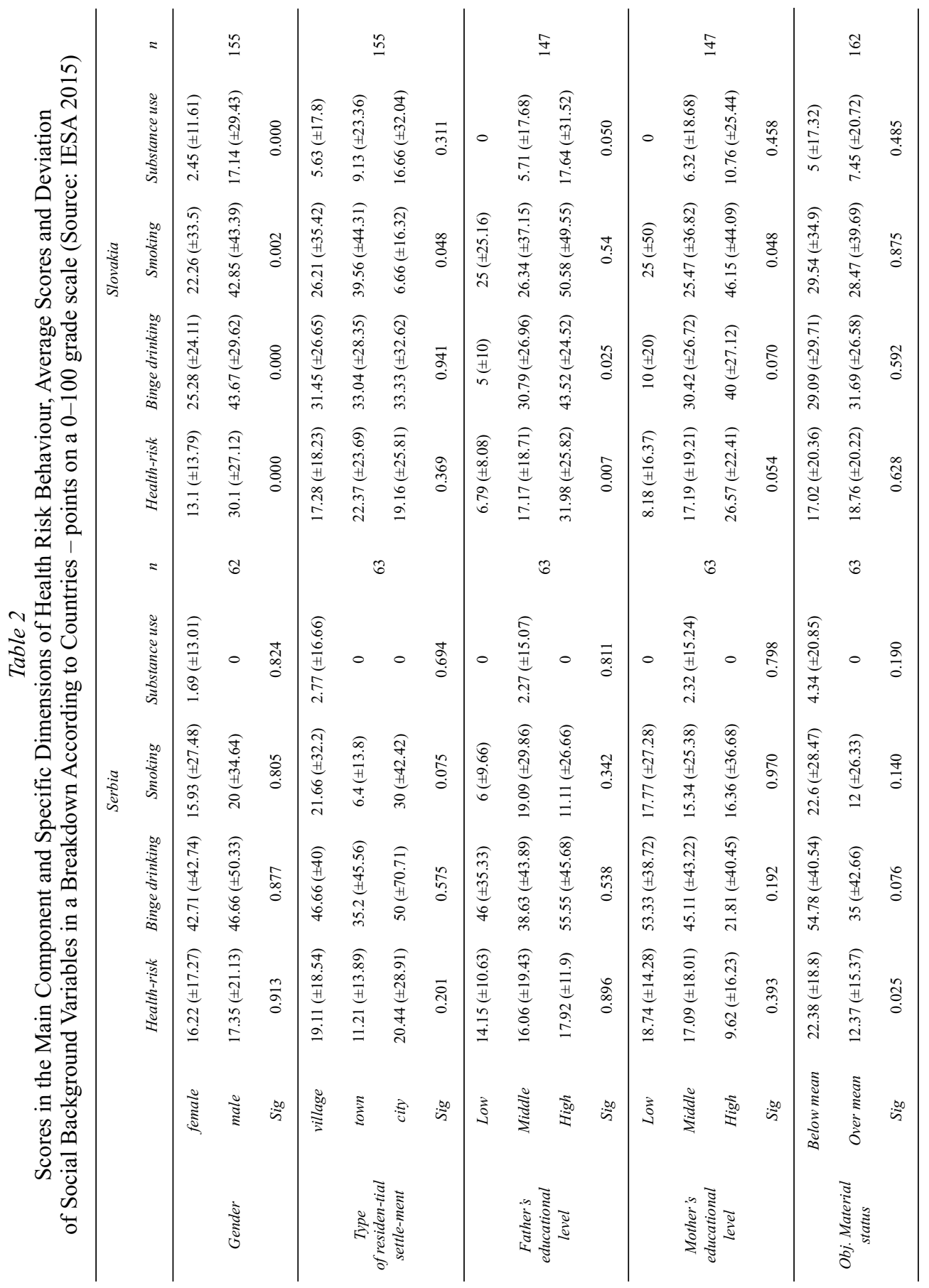




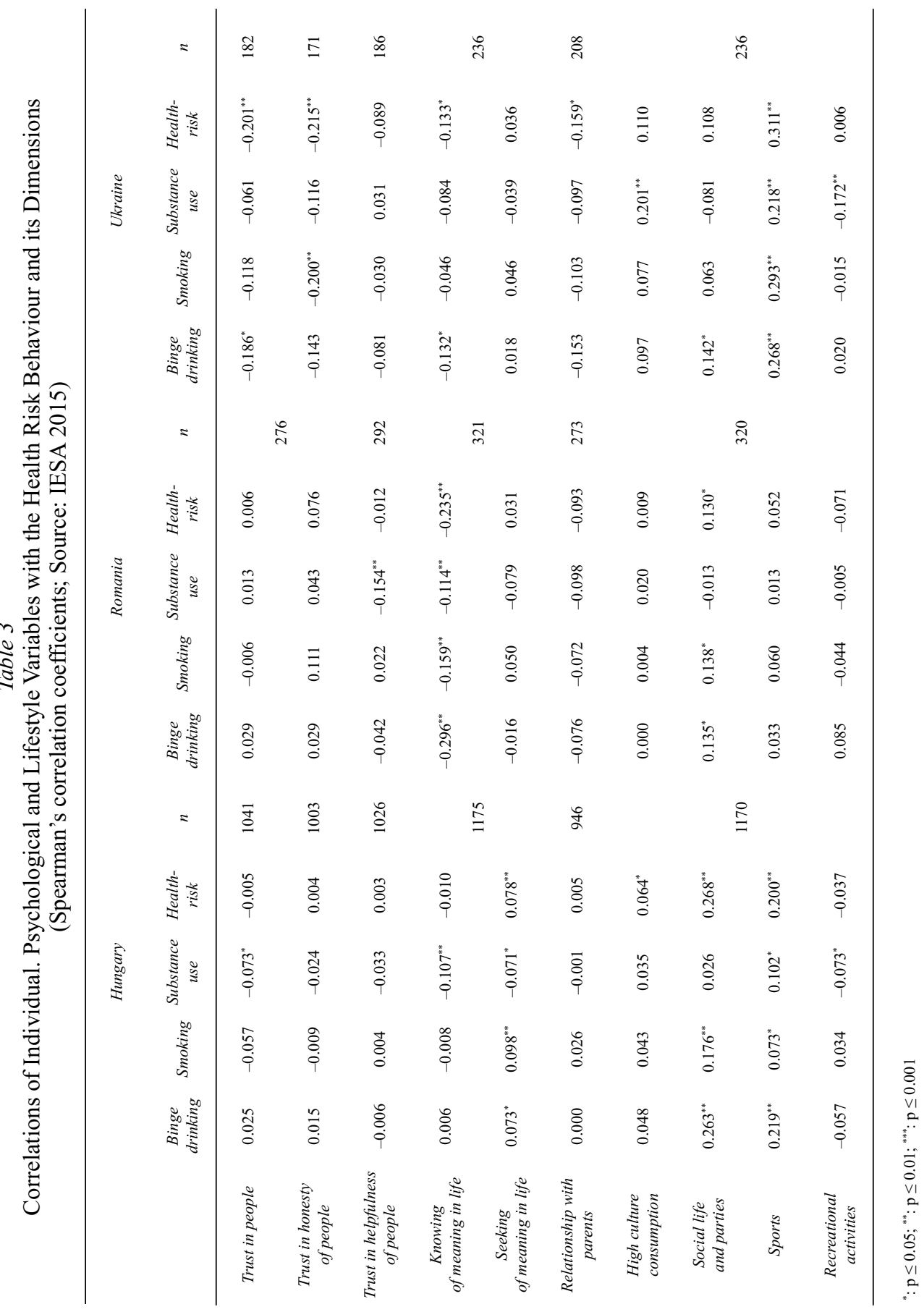


K. KOVÁCS

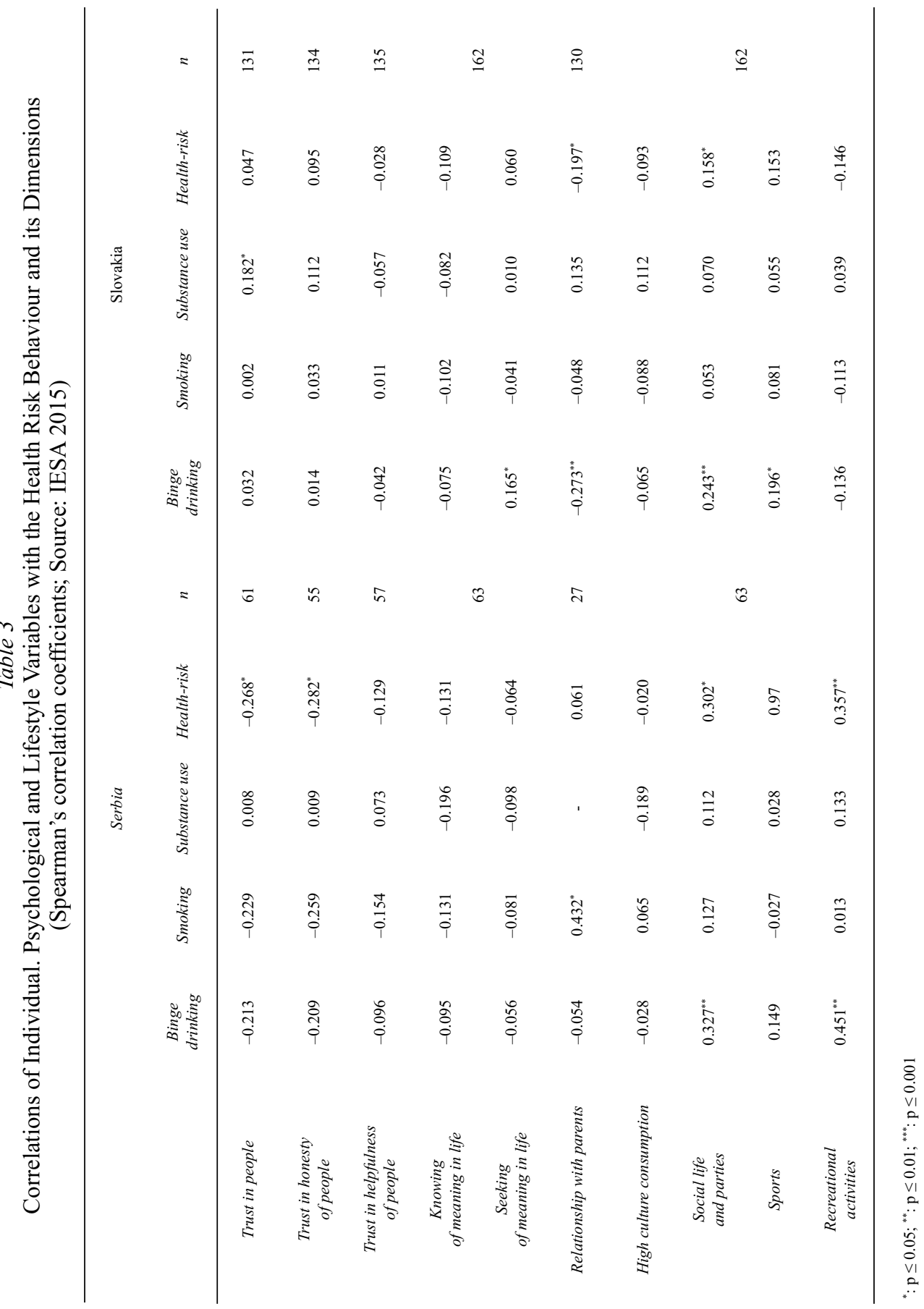


binge drinking and smoking and, in turn, at the combined indicator of health risk behaviour in Hungary $\left(\mathrm{M}_{\mathrm{HRB}}=18.17, \mathrm{SD}=16.71 ; \mathrm{M}_{\mathrm{bd}}=36.1, \mathrm{SD}=27.65 ; \mathrm{M}_{\text {smoking }}=\right.$ $29.89, \mathrm{SD}=39.39)$. As for the Romanian students, a smoking frequency of almost 10 points higher is characteristic of students in a better financial situation $(\mathrm{M}=31.35$, $\mathrm{SD}=45)$. On the other hand, in Serbia, students in a not very good financial status are susceptible to substance use $(\mathrm{M}=22.38, \mathrm{SD}=18.8)$. Among the students in the Voivodina we found that none of the social-demographic background variables played a significant role in certain dimensions of substance use, and the financial situation had a small role, but when the factors were examined as a combined component of risk behaviour, the small effects were added up. In this way, the disadvantage of students in a worse financial situation in terms of health consciousness became tangible.

\subsection{Interrelations between Individual, Psychological and Lifestyle Factors and Risk Behaviour}

The next part of the research was an examination of the interrelations between the individual, psychological, and lifestyle factors and the indicator and dimensions of health behaviour. For identifying the interrelations, we used Spearman's correlation (Table 3). All variables examined show some correlation with some of our dependent variables. The more a Hungarian student trusts people, the less likely he/she will use drugs. Similarly, a Subcarpathian student with a high degree of confidence in people is less likely to become a heavy drinker, and they are generally more health conscious $\left(\mathrm{r}=-0.201^{* *}\right)$, just like the students from the Voivodina $\left(\mathrm{r}=-0.268^{* *}\right)$, though in the Voivodina, we were unable to find a significant correlation between the specific dimensions. Contrary to these results, we found a positive relationship between trust in people and drug use $\left(\mathrm{r}=0.182^{*}\right)$. Among the students of Subcarpathia and the Voivodina, as the trust in people and also in people's honesty increases, the use of drugs decreases $\left(\mathrm{r}_{\mathrm{UA}}=-0.215^{* *}, \mathrm{r}_{\mathrm{SB}}=-0.282^{*}\right)$, and the former also smoke less due to the effect of their trust in people $\left(\mathrm{r}=-0.200^{* *}\right)$. Trust in people only has a negative correlation with the drug use of students in Romania: $\left(\mathrm{r}=-0.154^{* *}\right)$.

With the exception of the Serbian sub-sample, knowing, or searching for, the meaning of life was found to be in a significant correlation with some of the health risk behaviours. The most powerful connection was found among the students of Transylvania: knowing the meaning of life was strongly linked to all risk behaviours, and so with the combined indicator, as a protective factor $\left(\mathrm{r}=-0.235^{* *}\right)$. In Hungary it was powerfully linked to drug use $\left(\mathrm{r}=-0.107^{*}\right)$ and binge drinking $\left(\mathrm{r}=-0.132^{*}\right)$, and in the Ukraine to the combined indicator of risk behaviour $\left(\mathrm{r}=-0.133^{*}\right)$. When, however, a student in Hungary or in Slovakia does not know what the purpose of their life is or does not have any specific plan for the future, their life is therefore pointless, and that may be a risk factor of substance use for the former $\left(\mathrm{r}=0.078^{* *}\right)$, and binge drinking for the latter $\left(\mathrm{r}=0.165^{*}\right)$. As part of that research, PUSZTAI and MÁRKUS (2017) demonstrated that the proportion of students in the Highlands who 
do not yet know what purpose they may have in life is outstandingly high, and that in itself may lead to serious mental problems.

The findings of PIKÓ and KovÁCS (2010) suggest that the closer the parent-child relationship is, the more powerful the parental monitoring is, therefore it is less likely that the child will be a substance user. Family cohesion, a well-functioning family, is therefore an outstanding socio-cultural protective factor. The same was found among the students of Subcarpathia and the Highlands for binge drinking $\left(\mathrm{r}_{\mathrm{UA}}=-0.153^{*}, \mathrm{r}_{\mathrm{SK}}\right.$ $\left.=-0.273^{* *}\right)$ and the combined indicator of health risk behaviour $\left(\mathrm{r}_{\mathrm{UA}}=-0.159^{*}, \mathrm{r}_{\mathrm{SK}}=\right.$ $\left.-0.197^{*}\right)$. It is to be noted that among the Slovakian students, the relationship with the parents has the most powerful correlation with the factors concerned. The research also showed that the lenient attitude of parents is a risk factor in their children's substance use, and it may explain the fact that the closer the parent-child relationship in the Voivodina is, the more susceptible the children are to smoking $(\mathrm{r}=$ $\left.0.432^{*}\right)$.

The closest correlations were found at the social-partying way of spending free time, that is, this lifestyle has the most powerful and most obvious risk factor (CRANFORD et al. 2009). In Serbia, we found that this lifestyle had the strongest influence on the combined risk indicator $\left(\mathrm{r}=302^{*}\right)$, whereas in Hungary it exerted the most intensive influence on our dependent variables $\left(\mathrm{r}=268^{* *}\right)$. It is to be noted that this factor was found to be in close correlation with binge drinking as the most typical harmful activity in each of the countries examined. It applies primarily to Hungary $\left(\mathrm{r}=263^{* *}\right)$ and the Highlands $\left(\mathrm{r}=243^{* *}\right)$, while in Subcarpathia solely binge drinking was found to be interlinked with partying to a considerable extent $\left(\mathrm{r}=0.142^{*}\right)$. Then there is also other substance use (for instance in Hungary, smoking was also found to be powerfully present: $r=0.176^{* *}$, and drug use.

In accordance with the findings of earlier research projects (MARTENS et al. 2010), community/team sport is linked to binge drinking among Hungarian $(\mathrm{r}=$ $\left.0.219^{* *},\right)$, Ukrainian $\left(\mathrm{r}=0.268^{* *}\right)$, and Slovakian students $\left(\mathrm{r}=0.196^{*}\right)$. The combined indicator of health risk activities shows an unmistakable interrelation with sports $(\mathrm{r}$ $\left.=0.311^{* *}\right)$ in Subcarpathia. Another observation for Subcarpathia was the positive correlation between drug use and high culture consumption $\left(\mathrm{r}=201^{* *}\right)$. Recreation and free time include solitary activities such as reading and jogging, and these serve as protective factors against drug use in Hungary and Subcarpathia $\left(\mathrm{r}_{\mathrm{HU}}=-0.073^{*}, \mathrm{r}_{\mathrm{UA}}\right.$ $\left.=-0.172^{* *}\right)$. The strongest positive interrelation was found between sport and the combined indicator of health risk behaviour of Serbian students $\left(\mathrm{r}=0.357^{* *}\right)$. In the combined indicator, binge drinking plays an important role $\left(\mathrm{r}=0.451^{* *}\right)$.

\subsection{The Predictors of Health Risk Behaviour among Students}

Linear regression was used in order to survey the factors that influence the students' health risk behaviour in one model, controlled all the researched explanatory factors with each other (that is, the combined indicator; Table 4). This way, analysing and controlling the effects of all the variables, we were able to identify the factors 
influencing risk behaviour. It is of importance since the various explanatory factors are not independent of each other, and when two variables are examined only, these effects could not be screened. In the Serbian sub-sample, we found no significant interrelations, so the effect of the objective financial situation disappeared together with the other variables, thus in their case the factors we examined played no considerable role in their risk behaviours. As far as the Romanian students were concerned, gender did not play a major role, whereas in the other three countries, we found that, in accordance with the findings of earlier research (CRANFORD et al. 2009; STEPTOE et al. 2002; EMMONS et al. 1998; HunT \& EISENBERG 2010), men are in a bigger danger in terms of health risk behaviour (substance user males are overrepresented in Subcarpathia). In these countries, the effect of the gender is still there if the effects of all the variable are tested in one single model. Formerly detected interrelations of the socio-economic background variables disappeared; only the effect of the subjective financial situation is observable among the students in Hungary $(\beta=-0.085)$ : the lower a student rates their financial situation, the more susceptible they are to substance use.

The social-partying way of spending one's free time was the most powerful predictor of risk behaviour - independently of all the other variables - in Hungary, Romania, and the Ukraine $\left(\beta_{\mathrm{HU}}=0.248, \beta_{\mathrm{RO}}=0.226, \beta_{\mathrm{UA}}=0.335\right)$.

Regular pursuit of recreational activities such as reading and jogging ensures that Hungarian students refrain from the use of harmful substances $(\beta=-0.157)$. Jogging is a demanding physical activity that intensively trains the body and contributes to mental freshness as well. Jogging, especially when pursued regularly, is therefore not compatible with smoking or binge drinking, and it contributes to a health-conscious way of life in all dimensions of health behaviour. The negative effect of high culture consumption among Subcarpathian students has vanished, which is not surprising, since activities in this dimension of spending one's free time (going to museums, theatres, classical concerts, etc.) often requires financial resources, so it is not independent of the students' socio-cultural background. Sports, on the other hand, function as a protective factor, contrary to the results of some correlational analyses.

In addition to these two free time activities, trust in people influences the Subcarpathian students' risk behaviour, and protects them from substance use $(\beta=$ -0.303 ), independently of all the other influencing factors. With the Slovakian students, this factor contributes to risk behaviour $(\beta=0.262)$, as the correlational analysis indicates. Trust in people is a protective factor for the Slovakian students and lowers their substance use. A control of the variables showed that trust in people appeared as an influencing factor among Romanian students, resulting in a more frequent appearance of risk behaviour $(\beta=0.170)$. The strongest protective effect of knowing the meaning of life was detected among the Romanian students, as verified by the correlation examination and the regression analysis. It is clear that knowing the meaning of life, and the more stable image of a future coming with this, is one of the most important predictors of a health-conscious way of life among the students of Transylvania and the Partium $(\beta=-0.238)$. 
Table 4

The Predictors of Health Risk Behaviours in a Breakdown According to the Countries Examined ( $\beta$ regression coefficients; Source: IESA 2015)

\begin{tabular}{|c|c|c|c|c|}
\hline & $\begin{array}{c}\text { Hungary } \\
\beta\end{array}$ & $\begin{array}{c}\text { Romania } \\
\beta\end{array}$ & $\begin{array}{c}\text { Ukraine } \\
\beta\end{array}$ & $\begin{array}{c}\text { Slovakia } \\
\quad \beta\end{array}$ \\
\hline Gender ( 0 female, 1 male) & $0.140^{* * *}$ & 0.097 & $0.536^{* * *}$ & $0.343^{* *}$ \\
\hline Type of home settlement ( 0 county, I city/town) & 0.009 & 0.050 & 0.062 & 0.131 \\
\hline Father's educational level (in classes) & -0.031 & -0.028 & -0.045 & -0.130 \\
\hline Mother's educational level (in classes) & 0.000 & 0.143 & 0.031 & 0.184 \\
\hline Obj. material status (0-100 points) & 0.072 & 0.092 & 0.021 & 0.173 \\
\hline Subj. material status ( $0-80$ points) & $-0.085^{*}$ & -0.078 & 0.010 & 0.042 \\
\hline Trust in people (0-100 points) & 0.012 & -0.083 & $-0.303^{* *}$ & $0.262^{*}$ \\
\hline Trust in honesty of people ( $0-100$ points) & -0.006 & $0.170^{*}$ & 0.142 & 0.112 \\
\hline Trust in helpfulness of people (0-100 points) & 0.005 & -0.051 & -0.088 & $-0.338^{*}$ \\
\hline Knowing the meaning in life (0-100 points) & -0.062 & $-0.238^{* * *}$ & -0.097 & -0.007 \\
\hline Seeking the meaning in life (0-100 points) & 0.016 & 0.002 & 0.154 & -0.068 \\
\hline Relationship with parents ( $0-100$ points) & 0.048 & -0.115 & -0.050 & -0.115 \\
\hline High culture consumption ( $0-100$ points) & -0.082 & -0.099 & 0.153 & -0.160 \\
\hline Social life and parties (0-100 points) & $0.248^{* * *}$ & $0.226^{* *}$ & $0.335^{* *}$ & -0.051 \\
\hline Sports (0-100 points) & -0.086 & -0.173 & $-0.254^{*}$ & -0.083 \\
\hline Recreational activities (0-100 points) & $-0.157^{* * *}$ & -0.025 & -0.062 & -0.092 \\
\hline$R^{2}$ & 0.089 & 0.206 & 0.318 & $0.370^{*}$ \\
\hline
\end{tabular}

$\mathrm{p} \leq 0.05 ;{ }^{* *}: \mathrm{p} \leq 0.01 ;{ }^{* * *}: \mathrm{p} \leq 0.001$

\section{Summary and Conclusions}

Our research was a comparative survey among students in Hungary's Northern Plains Region, the ethnic Hungarian students in Romania's Partium and Transylvania regions, the Subcarpathian region of the Ukraine, the Voivodina of Serbia and the Highlands in Slovakia $(\mathrm{N}=2,017)$. Our goal was to map and compare the socio-cultural factors that influence students' health risk behaviour, and then we identified the influencing factors in each country.

The examination of the socio-economic status showed that this factor has a tangible effect in Hungary only; or, as far as smoking is concerned, a feeble effect in Slovakia. In the other three countries, hardly any effect - or none whatsoever - could 
be traced. When the influencing effects of all the explanatory variables were analysed in one single model, it was found that the effect of socio-cultural background was not present in any of the countries concerned, except in Hungary, where the subjective financial situation was found to be an influencing factor. The worse students regarded their financial situation, the more characteristic with them risk behaviour was. The subjective financial situation's role was verified in their earlier research: the selfevaluated socio-economic status of the young people was an important predictor of their psycho-social health. Our findings are in accordance with the results of the meta-analysis conducted by HANSON and CHEN (2007) in connection with the tobacco, alcohol, and marijuana consumption of young people (10-21 years). They found that, with the exception of smoking, social background did not have as powerful an effect on young people's health risk behaviour as it did in the adult population. All in all, however, those research findings appear to be justified that draw our attention to the fact that socio-economic status has little influence on the health and health risk behaviour of students and young people in general (HANSON \& CHEN 2007; Steptoe et al. 2002; PikÓ et al. 2013).

The examination of the effects of the gender revealed considerable influence in three of the countries concerned: males were exposed to the danger of health risk behaviour to a larger extent than women in Hungary, Subcarpathia and the Highlands. There is another common factor influencing the substance use of university students in Hungary, the Ukraine, and Romania: the social and partying way of life and its related activities. In these three countries, regular participation in campus parties is the most convincing predictor of substance use. An organic part of student life is partying, spending time with peers, joining university communities, etc. The more students are involved in such free time activities, the more they are exposed to the various forms of health risk behaviour, particularly binge drinking. Even when a student is fully aware of the potential consequences of excessive alcohol consumption, at a party, the expectations and pressure of peers, the basic norms of campus life, the value system of partying, all may easily override the sense of danger, and the student underestimates or disregards the possible consequences. For a lot of young people, these are the first occasions to be away from home, when they no longer need to ask for parental permission to go to a party, and their fellow students introduce them into student life like some sort of an inauguration procedure. Partying, social life will then soon become a part of daily routine in the life of a 'typical' student.

Recreational activities such as reading and running function as protective factors for students in Hungary. The extra knowledge and information gained from reading, the benevolent effects of running on physical health and fitness offer a higher level of health consciousness, and students will avoid health risk behaviour in the Northern Plains Region.

Among the Subcarpathian students, both sports and the general trust in other people result in a generally lower level of substance use, when all the other factors are controlled. The more sports students participate in - ball games, cycling, swimming, trekking, team sports - the less likely they will turn towards the use of harmful 
substances. Although the results of a number of earlier research projects verified the positive effects of sports on the heart and circulatory system, osteoporosis, mental problems, depression, and it also improves the person's self-confidence, etc., (HARRISON \& NARAYAN 2003; PATE et al. 2000; Frost \& MCKelvie 20-05; FoX 1999) the interrelations between sports and risk behaviours are not yet fully clear. In the case of the Subcarpathian students, we discovered that when the other influencing factors are controlled, sports contribute to the other elements of a health-conscious way of life, notably to a lower substance use. It is important to know that the students of the region's only Hungarian higher education institution, Ferenc Rákóczi II Hungarian College of Subcarpathia, are supposed to participate in the work of some extracurricular cultural or professional association every semester in order to complete their studies (they need a standard verification of the fact in their registration course books). Sports clubs are extremely popular among the extracurricular activities, so the majority of the students are members of the sports associations, and they very often spend their free time together even when they are not actually participating in sports. In addition, previous research results have acknowledged the negative effects of smoking and alcohol use on athletic performance (WEAVER et al. 2013).

Among students of the Partium and Transylvania, trust in other people is a risk factor, whereas knowing the meaning of life serves as a protective factor. It should be an important goal for the heads, teachers of principally Romanian higher education institutions, and staff of mental-hygienic organisations, to recognise when a student is oblivious of the purposes of their life and future, and they should assist them in finding a sensible purpose, since these students may easily choose some substitute - including harmful substances - in order to find the experiences they miss.

Our regression analysis failed to reveal significant effects among the students in Serbia. The reason might be the low number of the Serbian subsample, but the bivariable analyses pointed out that close connections with parents, and trust in other people and other people's helpfulness, led to lower health risk behaviour. A socialpartying way of life, on the other hand, means a higher health risk behaviour occurrence among the students.

We regard it as an important finding of our research that we have been able to identify individual protective and risk factors in the geographical regions concerned. In the sub-sample from the Highlands, out of all the bi-variable interrelations, only the effects of the trust in other people and the trust in people's helpfulness remained, with opposite polarities. The first is a risk, while the second is a protective factor against substance use. Because of the special situation ethnic minorities experience on the other side of the borders, social capital and individual level of trust as a part of it plays a particularly important role in their life, and the cultural and community activities related to the ethnic roots and ethnic background constitute a part of their cultural capital. This was the point where we were able to apprehend the differences between the countries, which had been one of our major objectives. It requires further examination, and it probably has deep social and cultural roots in different countries, that the general trust in other people reduces the occurrence of risk behaviours in 
Subcarpathia, and increases it among the students in the Highlands, just as in Rumania. The examination of these phenomena requires deeper analyses, but some of the findings of earlier researches in the Highlands underpins our assumption. These results suggest that although these students live in a generally better financial situation than those in the other regions, they also remain exposed to powerful assimilational influences that adversely affect their identity and mental welfare, threatening them with the loss of their ethnic and social roots (PusZTAi \& MÁrkus 2017). These influences appear in their trust in other people.

We may therefore conclude that the prevention programmes going on at the universities should primarily target students' community free time activities, concentrating on the use of harmful substances and their short- and long-term effects, particularly among men. Recreational or free-time sports activities may be incorporated into the preventional programmes. Sports activities contribute to preserving student health, and at the same time, they may make students more health conscious. The desired result is an increase in the number of healthier students, who do regular physical activity, and who refrain from the use of harmful substances.

\section{References}

BAndura, A. (1977) 'Self-Efficacy: Toward a Unifying Theory of Behavioural Change', Psychological Review 84, 191-215 (http://dx.doi.org/10.1037/0033-295X.84.2.191).

Baranyai, R., G. Bakos, A. Steptoe, J. Wardle \& M. Kopp (2006) 'Egyetemisták és föiskolások szívbetegséggel kapcsolatos egészségmagatartása, rizikótudata és hiedelmei', Mentálhigiéné és Pszichoszomatika 7, 125-38 (https://doi.org/10.1556/Mental.7.2006.2.4).

Berg, C.J., G.L. SCHAUER, O.A. Asfour, A.N. Thomas \& J.S. Ahluwalia (2011) 'Psychosocial Factors and Health-Risk Behaviors Associated with Hookah Use among College Students', Journal of Addiction Research \& Therapy Suppl 2 (https://doi.org/10.4172/2155-6105.S2001).

BogG, T. \& B.W. RoberTs (2004) 'Conscientiousness and Health-Related Behaviors: A MetaAnalysis of the Leading Behavioral Contributors to Mortality', Psychological Bulletin 130, 887-919 (http://dx.doi.org/10.1037/0033-2909.130.6.887).

BRASSAI, L. (2011) Az élet értelmessége, mint az egészségmagatartás védőfaktora serdülőkorban (PhD. Diss., Semmelweis University, Budapest).

Catalano, R.F., S. Oesterle, C.B. Fleming \& J.D. Hawkins (2004) 'The Importance of Bonding to School for Healthy Development: Findings from the Social Development Research Group', Journal of School Health 74, 252-61.

CRANFORD, J.A., D. EisenBerg \& A.M. SERRAS (2009) 'Substance Use Behaviors, Mental Health Problems, and Use of Mental Health Services in a Probability Sample of College Students', Addictive Behaviors 34, 134-45 (http://dx.doi.org/10.1016/j.addbeh.2008.09.004).

Croll, J., D. Neumark-Sztainer, M. Story \& M. Ireland (2002) 'Prevalence and Risk and Protective Factors Related to Disordered Eating Behaviors among Adolescents: Relationship to Gender and Ethnicity', Journal of Adolescent Health 31, 166-75.

Emmons, K.M., H. Wechsler, G. Dowdall \& M. Abraham (1998) 'Predictors of Smoking among US College Students', American Journal of Public Health 88, 104-07.

Fox, K.R. (1999) 'Influence of Physical Activity on Mental Well-being', Public Health Nutrition $3,411-18$. 
Frost, J. \& S.J. McKelvie (2005) 'The Relationship of Self-Esteem and Body Satisfaction to Exercise Activity for Male and Female Elementary School, High School, and University Students', Athletic Insight 4, 36-49.

Greene, G. W., S. M. Schembre, A. A. White, S. L. Hoerr, B. W. Phillips, K. K. Kattelmann, \& B. BLISSMER (2011) 'Identifying Clusters of College Students at Elevated Health Risk Based on Eating and Exercise Behaviors and Psychosocial Determinants of Body Weight', Journal of American Dietetic Association 111, 394-400 (http://dx.doi.org/10.1016/j.jada. 2010.11.011).

Hanson, M.D. \& E. Chen (2007) 'Socioeconomic Status and Health Behaviors in Adolescence: A Review of the Literature', Journal of Behavioral Medicine 30, 263-85 (http://dx.doi.org/ 10.1007/s10865-007-9098-3)

HARRISON, P.A. \& G. NARAYAN (2003) 'Differences in Behavior, Psychological Factors, and Environmental Factors Associated with Participation in School Sports and other Activities in Adolescence', Journal of School Health 3. 113-20.

Hawkins, J. D. \& J. G. WeIs (1985) 'The Social Development Model: An Integrated Approach to Delinquency Prevention', The Journal of Primary Prevention 6, 73-97 (http://dx.doi.org/ 10.1007/BF01325432).

Hawkins, J. D., R. F. Catalano \& J. Y. Miller (1992) 'Risk and Protective Factors for Alcohol and Other Drug Problems in Adolescence and Early Adulthood: Implications for Substance Abuse Prevention', Psychological Bulletin 112, 64-105.

Hawkins, J.D., R.F. Catalano, R. Kosterman, R. Abbott \& K.G. Hill (1999) 'Preventing Adolescent Health-Risk Behaviors by Strengthening Protection during Childhood', Archives of Pediatrics \& Adolescent Medicine 153, 226-34.

HEGEDŰs, R. (2016) 'Számok-arányok-mintázatok a felsőoktatásba felvett hátrányos helyzetủek esetében', Modern Geográfia 3, 1-14.

Hunt, J. \& D. Eisenberg (2010) 'Mental Health Problems and Help-Seeking Behavior among College Students', Journal of Adolescent Health 1, 3-10 (http://dx.doi.org/10.1016/j.jadohealth.2009.08.008).

KovÁcs, K. (2012) 'Egyetemisták és káros szenvedélyek: Rizikó- és védőfaktorok a debreceni egyetemisták egészségmagatartásában’ in Á. DusA, K. KovÁcs, Sz. NYüsTi, Zs. MÁRKus \& A. SÖRÉs, eds., Egyetemi élethelyzetek: Ifjúságszociológiai tanulmányok (Debrecen: Debrecen UP) 2:145-64.

KovÁcs, K. (2015) 'Teacher Education Students' Leisure Activities and State of Health' in G. Pusztai \& T. Ceglédi, eds., Professional Calling in Higher Education (Nagyvárad \& Debrecen: Partium Press, Personal Problems Solution, Új Mandátum Kiadó) 129-38.

Martens, M.P., K. Dams-O’Connor \& N.C. Beck (2006) 'A Systematic Review of College Student-Athlete Drinking: Prevalence Rates, Sport-Related Factors, and Interventions', Journal of Substance Abuse Treatment 3, 305-16 (http://dx.doi.org/10.1016/j.jsat.2006.05.004).

Martos, T. \& B. KonKoly-Thege (2012) 'Aki keres, és aki talál - az élet értelmessége keresésének és megélésének mérése az Élet Értelme Kérdőív Magyar változatával', Magyar Pszichológia Szemle 1, 125-26 (10.1556/MPSzle.67.2012.1.8).

Miller, J.W., T.S. Naimi, R.D. Brewer \& S.E. Jones (2007) 'Binge Drinking and Associated Health risk Behaviors among High School Students’, Pediatrics 119, 76-85 (http://dx.doi. org/10.1542/peds.2006-1517).

O’MAlLey, P.M. \& L.D. Johnston (2002) 'Epidemiology of Alcohol and other Drug Use among American College Students', Journal of Studies on Alcohol, Supplement 14, 23-39.

Pate, R.R., S.G. Trost, S. Levin \& M. Dowda (2000) 'Sports Participation and Health-Related Behaviors among US Youth', Archives of Pediatrics and Adolescent Medicine 9, 904-11.

PIKÓ, B. (2002) Egészségtudatosság serdülökorban (Budapest: Akadémiai Kiadó) 
PIKÓ, B. (2010) ‘Közösségi hatóképesség és más társas befolyás szerepe a serdülők dohányzásában és alkoholfogyasztásban' in B. PIKÓ, ed., Védőfaktorok nyomában: A káros szenvedélyek megelözése és egészségfejlesztés serdülőkorban (Budapest: L'Harmattan \& Nemzeti Drogmegelözési Intézet) 87-101.

PiKÓ, B. \& L. BRASSAI (2007) 'Cultural Values and Health-Related Behaviors: A Comparison of Hungarian and Transylvanian Youth', European Journal of Mental Health 2, 171-81 (http://dx.doi.org/10.1556/EJMH.2.2007.2.3).

Pikó, B. \& K.M. FitzPATRICK (2001) 'Does Class Matter? SES and Psychosocial Health among Hungarian Adolescents', Social Science \& Medicine 53, 817-30.

PIKÓ, B.F. \& E. KovÁcs (2010) 'Do Parents and School Matter? Protective Factors for Adolescent Substance Use', Addictive Behaviors 35, 53-56 (http://dx.doi.org/10.1016/j.addbeh. 2009. 08.004).

PiKÓ, B.F., L. BRASSAi \& K.M. FitZPATRICK (2013) 'Social Inequalities in Self-Perceived Health: Comparing Hungarian and Ethnic Minority Adolescents from Transylvania, Rumania', European Journal of Mental Health 81, 29-45 (http://dx.doi.org/10.5708/EJMH.8.2013.1.2).

PuszTAi G. (2011) A láthatatlan kéztől a baráti kezekig (Budapest: Uj Mandátum).

Pusztai G. (2015) Pathways to Success in Higher Education (Frankfurt a.M.: Peter Lang).

Pusztai, G. \& T. Ceglédi (2015) 'Teacher Education Students in Central and Eastern Europe' in Pusztai G. \& T. Ceglédi eds., Professional Calling in Higher Education: Challenges of Teacher Education in the Carpathian Basin (Oradea \& Debrecen: Partium, Persional Problems Solution, Új Mandátum) 7-11.

PuszTAI, G. \& Zs. MÁRKus (2017) 'Magyar hallgatók a Kárpát-medence felsőoktatási intézményeiben' in PuszTaI G. \& Zs. MÁrkus. eds., Szülöföldön magyarul: Iskolák és diákok a határon túl (Debrecen: Debreceni Egyetemi) 129-54.

Pusztai, G., K. Kovács, K.E. KovÁcs \& B.E. Nagy (2017) 'The Effect of Campus Environment on Students' Health Behaviour in Four Central European Countries', Journal of Social Research \& Policy 8:1, 1-14.

Putnam, R. (1995) 'Bowling Alone: America's Declining Social Capital', Journal of Democracy $6,65-78$.

Simantov, E., C. Schoen \& J.D. Klein (2000) 'Health-Compromising Behaviors: Why do Adolescents Smoke or Drink? Identifying Underlying Risk and Protective Factors', Archives of Pediatrics \& Adolescent Medicine 154, 1025-33.

SKRABSKI, Á. (2003) Társadalmi tőke és egészségi állapot az átalakuló társadalomban (Budapest: Corvinus).

Steger, M.F., P., Frazier, S. Oishi \& M. Kaler (2006) 'The Meaning in Life Questionnaire: Assessing the Presence of and Search for Meaning in Life', Journal of Counseling Psychology 53, 80-93 (http://dx.doi.org/10.1037/0022-0167.53.1.80).

Steptoe, A. \& J. WARdLE (2001) 'Health Behaviour, Risk Awareness and Emotional Well-being in Students from Eastern Europe and Western Europe', Social Science \& Medicine 53, $1621-30$.

Steptoe, A., J. Wardle, W. Cui, F. Bellisle, A.M. Zotti, R. Baranyai \& R. Sanderman (2002) 'Trends in Smoking, Diet, Physical Exercise, and Attitudes toward Health in European University Students from 13 Countries, 1990-2000', Preventive Medicine 35, 97-104.

SzATMÁri, Z., N. TARI-KereszTes, A. PÁLInKÁs \& A. TóTH (2012) 'Társas környezet, egészségmagatartás és egészség: Szegedi egyetemisták életmódjának vizsgálata szabadidős fizikai aktivitásuk tükrében', Rekreáció 1, 8-12 (http://dx.doi.org/10.21486/recreation.2011.1.1.1).

TAKakura, M. (2011) 'Does Social Trust at School Affect Students' Smoking and Drinking Behavior in Japan?' Social Science \& Medicine 72, 299-306 (http://dx.doi.org/10.1016/j. socscimed.2010.11.003). 
TAliaferro, L.A., B.A. Rienzo \& K.A. Donovan (2010) 'Relationships Between Youth Sport Participation and Selected Health Risk Behaviors From 1999 to 2007', Journal of School Health 80, 399-410 (http://dx.doi.org/10.1111/j.1746-1561.2010.00520.x).

Vaez, M. \& L. Laflamme (2003) 'Health Behaviors, Self-Rated Health, and Quality of Life: A Study among First-Year Swedish University Students', Journal of American College Health 51, 156-62 (http://dx.doi.org/10.1080/07448480309596344).

Von Ah, D., S. Ebert, A. Ngamvitroj, N. Park \& D. H. Kang (2004) 'Predictors of Health Behaviours in College Students', Journal of Advanced Nursing 5, 463-74 (http://dx.doi. org/10.1111/j.1365-2648.2004.03229.x).

Weaver, C. C., M. P. Martens, J. M. Cadigan, S. K. Takamatsu, H. R. Treloar \& E.R. Pedersen (2013) 'Sport-Related Achievement Motivation and Alcohol Outcomes: An Athlete-Specific Risk Factor among Intercollegiate Athletes', Addictive behaviours 38, 2930-36 (http://dx.doi. org/10.1016/j.addbeh.2013.08.021).

Wechsler, H., G. W. Dowdall, A. Davenport, \& S. Castillo (1995) 'Correlates of College Student Binge Drinking', American Journal of Public Health 85, 921-26. 